\title{
Real-life data of tenofovir disoproxil fumarate and tenofovir alafenamide fumarate in the patients with chronic hepatitis B: a single-center experience
}

\author{
(D) Mustafa Akar \\ Health Sciences University, Bursa Yüksek İhtisas Training and Research Hospital, Department of Gastroenterology, Bursa, Turkey
}

Cite this article as: Akar M. Real-life data of tenofovir disoproxil fumarate and tenofovir alafenamide fumarate in the patients with chronic hepatitis B: A single-center experience. Anatolian Curr Med J 2021; 3(3); 239-245.

\begin{abstract}
Aim: Chronic hepatitis B (CHB) infection can cause liver cirrhosis and hepatocellular carcinoma. In this study, it was aimed to evaluate the efficacy of tenofovir disoproxil fumarate (TDF) and tenofovir alafenamide fumarate (TAF) on clinical parameters, glomerular filtration rate (GFR), and phosphorus metabolism in the patients with CHB.

Material and Method: Eighty one patients with CHB treated with TDF were included in the study retrospectively. Twenty seven of them switched from TDF to TAF during the follow-up were considered as TAF group. Fifty four patients continued TDF were evaluated as TDF group.

Results: The mean ages of the patients were $45 \pm 12$ and $48 \pm 15$ years, and the mean durations of TDF treatment were $31 \pm 20$ and $52 \pm 32$ months in the TDF and TAF groups, respectively. The mean duration of TDF treatment was significantly higher in the TAF group (p: 0.01). The mean GFR and serum phosphorus levels of the patients before/after the TDF treatment were $99 / 103$ $\mathrm{ml} / \mathrm{min}$ and $2.9 / 3.1 \mathrm{mg} / \mathrm{dl}$ in the TDF group, respectively. The mean GFR and serum phosphorus levels of the patients before the TDF treatment/at the time of the switch/after the TAF treatment were $90 / 100 / 102 \mathrm{ml} / \mathrm{min}$ and $2.8 / 2.3 / 2.9 \mathrm{mg} / \mathrm{dl} \mathrm{in}$ the TAF group, respectively. Increase in the mean level of phosphorus after the switch were found significant $(\mathrm{p}<0.05)$. The mean GFR levels of the patients switched due to low GFR showed a significant decrease under the TDF treatment and a significant increase after the TAF treatment. A significant improvement was observed in the total hip and spine T score of the patients who were switched to TAF due to osteoporosis.

Conclusion: TAF used in the treatment of $\mathrm{CHB}$ has a similar efficacy with TDF, and it has more positive effects on creatinine clearance, bone mineral density, and phosphorus metabolism than TDF.

Keywords: Chronic hepatitis B, hypophosphatemia, osteoporosis, tenofovir disoproxil fumarate, tenofovir alafenamide fumarate.
\end{abstract}

\section{INTRODUCTION}

It is estimated that approximately 257 million people worldwide are chronically infected with hepatitis B virus, which is one of the major causes of chronic liver disease, liver cirrhosis, and hepatocellular carcinoma (HCC) (1$3)$. In these patients, the level of viral load in the serum and the risk of developing liver cirrhosis, HCC, and other liver-related complications are directly related (4). Therefore, it is a necessity of suppressing the viral load at undetectable levels with treatment in patients with chronic hepatitis B (CHB).

There are 6 oral nucleos(t)ide analogue antiviral agents that have been approved by the Food and Drug Administration (FDA) so far in the treatment of $\mathrm{CHB}$ (5).
Lamivudine was the first oral antiviral agent to be approved for this purpose in 1998. One of the most important disadvantages of using lamivudine is the development of resistance at a rate of $60-70 \%$ in 5 years $(6,7)$. By 2005 , entecavir, which has a higher resistance barrier compared to lamivudine, was introduced, especially in naive patients. However, in 5 years with entecavir, the resistance rate found in naive patients was $1.2 \%$, while this rate was $51 \%$ in lamivudine-resistant patients $(8,9)$. For this reason, drugs with higher resistance barriers have been developed over time. Tenofovir disoproxil fumarate (TDF), which has been used for CHB since 2008, has a very high resistance barrier and no resistance has been 
reported in 8 years of period (10). However, some of the patients using TDF have reported the risk of developing renal tubular dysfunction and osteopenia/osteoporosis in the long term (11).

Tenofovir alafenamide fumarate (TAF), which is a prodrug just like TDF and contains tenofovir, received FDA approval in the treatment of CHB in $2016(5,12)$. It has been reported that TAF, which contains about 90\% lower tenofovir concentration than TDF, has a high resistance barrier like TDF and excellent efficiency, and also has more positive effects on renal functions, serum phosphorus levels, and bone metabolism (13-16). At the same time, no resistance has been reported in the 3-year use of TAF (17).

Phosphorus is involved in cell membrane integrity, nucleic acid formation, ATP production, cell signaling, buffering of acid-base balance, and bone mineralization. Therefore, keeping serum phosphorus levels within normal limits is crucial (18). With the change in the national reimbursement guideline for about the last 2 years, the use of TAF in CHB patients in Turkey has been approved with the established rules. In this study, it was aimed to evaluate the efficacy of TDF and TAF on clinical parameters, GFR, and phosphorus metabolism in the patients with $\mathrm{CHB}$.

\section{MATERIAL AND METHOD}

Ethics committee approval of the study was obtained from Health Sciences University Bursa Yüksek İhtisas Training and Research Hospital Ethics Committee (Date: 17.02.2021, Decision No: 2011-KAEK-25 2021/0203) The study was conducted in accordance with the Declaration of Helsinki ethical standards.

The patients with $\mathrm{CHB}$ treated with $\mathrm{TDF}$ in the gastroenterology outpatient clinic, Bursa Yüksek İhtisas Training and Research Hospital, between March 2016 and March 2021 were evaluated retrospectively. Demographic and clinical data of the patients were obtained from the outpatient follow-up files. The patients who were switched from TDF to TAF aligned with the national reimbursement guideline during the follow-up were considered as TAF group. The remaining patients continued on TDF treatment were considered as TDF group. The patients who have not completed the first 3 months of TAF use and did not attend regular followup were excluded. In addition, patients with less than 6 months of TDF use were also excluded from the study. TDF to TAF switch criteria were defined as follows: Hypophosphatemia; serum phosphorus level $<2.5 \mathrm{mg} /$ $\mathrm{dl}$, osteoporosis; $\mathrm{T}$ score $<-2.5$ on BMD, low GFR; creatinine clearance $<60 \mathrm{ml} / \mathrm{min}$, and detectable HBV DNA; HBV DNA level $>20 \mathrm{IU} / \mathrm{ml}$. Abnormal alanine aminotransferase (ALT) was defined according to the reference laboratory (for male $>41 \mathrm{U} / \mathrm{L}$, for female $>33$ $\mathrm{U} / \mathrm{L})$. GFR is calculated with modification of diet in renal disease (MDRD) formula (19). Hepatic fibrosis staging and histological activity index (HAI) score were assessed according to the Modified Ishak Scoring System (20).

\section{Statistical Analyses}

The data were analysed using the Statistical Package for the Social Sciences version 21.0 (SPSS Inc., Chicago, Illinois, USA). Conformity to normal distribution was evaluated with the "Kolmogorov-Smirnov" test. The data that could be measured and provided the parametric condition were given as mean \pm standard deviation. For data that could be measured and did not meet the parametric condition, the distribution was defined as median (min.-max.). Categorical variables were shown as numbers and percentages. Comparison of laboratory parameters during treatment was performed with repeated measures analysis of variance (ANOVA) test. Bonferroni test was used in multiple comparisons. In all statistical evaluations, $\mathrm{p}<0.05$ was considered significant.

\section{RESULTS}

In total 115 patients with CHB treated with TDF were evaluated retrospectively. 29 patients were excluded (22 had not regular follow-up, seven had a follow-up time $<6$ months). Thirty two of the remaining 86 patients were switched from TDF to TAF during the follow-up. The reasons for the switch were as follows; 25 (78\%) hypophosphatemia, three (9.4\%) low GFR, two (6.3\%) osteoporosis, and two (6.3\%) detectable HBV DNA under the TDF treatment. Five patients switched from TDF to TAF were excluded in the hypophosphatemia group (four did not complete the 3-month TAF usage period and one left the treatment voluntarily). Thus, 27 patients were evaluated as the TAF treatment group. Fifty four patients who continued the TDF treatment were evaluated as the TDF group (Figure 1).

In the TDF group: The mean age of the patients was $45 \pm 12$ years, 36 of them $(67 \%)$ were male. The mean duration of TDF treatment was $31 \pm 20$ (range: 6-96) months. Four (7\%) of the patients had HBeAg positivity and $11(20 \%)$ had a diagnosis of cirrhosis. As a comorbid disease; eight (15\%) patients had hypertension and six (11\%) patients had diabetes mellitus. The median HBV DNA level before the TDF treatment was $10.2 \times 103 \mathrm{IU} /$ $\mathrm{ml}$. The mean HAI and fibrosis values were $8( \pm 2.4)$ and $2.8( \pm 1.5)$, respectively (Table $\mathbf{1})$. The mean aspartate aminotransferase (AST), ALT, GFR, and serum phosphorus level of the patients before/after the TDF treatment were $48 / 23 \mathrm{U} / \mathrm{L}, 67 / 25 \mathrm{U} / \mathrm{L}, 99 / 103 \mathrm{ml} / \mathrm{min}$, and $2.9 / 3.1 \mathrm{mg} / \mathrm{dl}$, respectively. Decrease in the mean 
values of transaminases after the TDF treatment was significant $(\mathrm{p}<0.001)$. There were no significant changes in the mean GFR value and serum phosphorus level

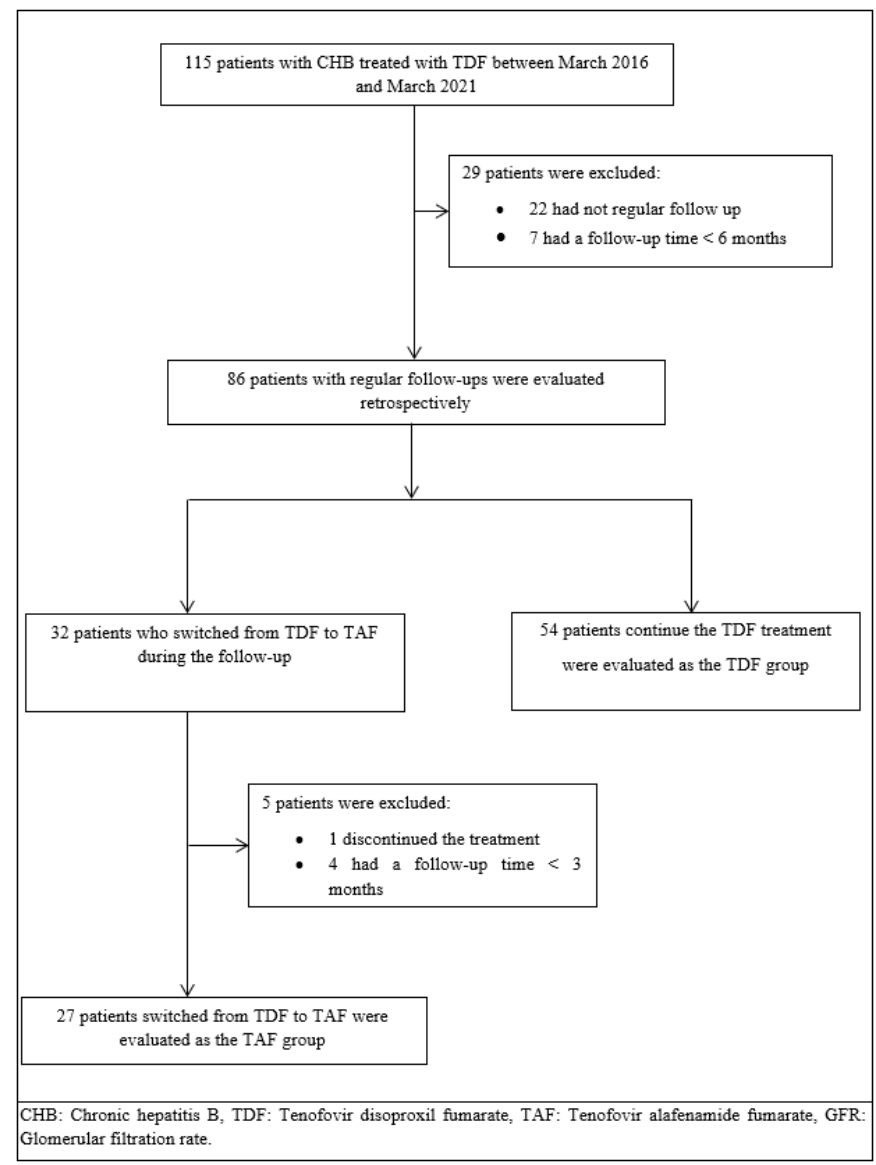

under the TDF treatment. Detectable HBV DNA was detected in two (4\%) patients under the TDF treatment. The mean duration of TDF use in the patients with detectable HBV DNA was 17 months. Abnormal ALT level was detected in five (9\%) patients under the TDF treatment. Three of these patients had grade-2 hepatosteatosis on ultrasonography. The other two patients had liver cirrhosis. No HBsAg loss or HBeAg seroconversion was observed during the treatment course (Table 2).

\section{Table 2. Changes in laboratory parameters of the patients} continuing the TDF treatment (n: 54)

\begin{tabular}{|c|c|c|c|}
\hline Variables & $\begin{array}{c}\text { Baseline } \\
\text { (before TDF) }\end{array}$ & $\begin{array}{l}\text { The latest } \\
\text { follow up } \\
\text { (after TDF) }\end{array}$ & $\mathbf{p}$ \\
\hline $\mathrm{AST}^{\star}(\mathrm{U} / \mathrm{L})$ & $48( \pm 50)$ & $23( \pm 10)$ & $<0.001$ \\
\hline $\operatorname{ALT}^{\star}(\mathrm{U} / \mathrm{L})$ & $67( \pm 80)$ & $25( \pm 14)$ & $<0.001$ \\
\hline $\begin{array}{l}\text { Prevalence of abnormal } \\
\text { ALT }^{\star * \star}, \mathrm{n}(\%)\end{array}$ & $23(43)$ & $5(9)$ & 0.002 \\
\hline $\begin{array}{l}\text { Serum phosphorus* } \\
(\mathrm{mg} / \mathrm{dl})\end{array}$ & $2.9( \pm 0.5)$ & $3.1( \pm 0.7)$ & 0.4 \\
\hline $\mathrm{GFR}^{*}, \mathrm{ml} / \mathrm{min}$ & $99( \pm 13)$ & $103( \pm 16)$ & 0.5 \\
\hline HBsAg loss, $n$ & - & 0 & - \\
\hline $\mathrm{HBe} A g$ seroconversion, $\mathrm{n}$ & - & 0 & - \\
\hline $\begin{array}{l}\text { Detectable HBV DNA, n } \\
(\%)\end{array}$ & $54(100)$ & $2(4)$ & - \\
\hline \multicolumn{4}{|c|}{$\begin{array}{l}\text { AST: Aspartate aminotransferase, ALT: Alanine aminotransferase, TDF: Tenofovir } \\
\text { disoproxil fumarate, TAF: Tenofovir alafenamide fumarate, GFR: Glomerular } \\
\text { filtration rate } \\
* \text { *: Mean ( } \pm \text { Standard deviation) } \\
* * \text { : Median (min-max) } \\
* * \text { : Normal ALT cutoffs for male } 41 \mathrm{U} / \mathrm{L} \text {, female } 33 \mathrm{U} / \mathrm{L} \text { according to the reference } \\
\text { laboratory }\end{array}$} \\
\hline
\end{tabular}

Figure 1. Flow diagram of the current study

\begin{tabular}{|c|c|c|c|}
\hline Characteristics & $\begin{array}{c}\text { TDF group } \\
(\mathrm{n}: 54)\end{array}$ & $\begin{array}{c}\text { TAF group } \\
(\mathbf{n}: 27)\end{array}$ & $\mathbf{p}$ \\
\hline Age $^{\star}$ (years) & $45 \pm 12$ & $48 \pm 15$ & 0.3 \\
\hline Gender (M), n (\%) & $36(67)$ & $16(59)$ & 0.5 \\
\hline HBeAg positivity, n (\%) & $4(7)$ & $3(11)$ & 0.3 \\
\hline Cirrhosis, $\mathrm{n}(\%)$ & $11(20)$ & $6(22)$ & 0.6 \\
\hline $\mathrm{HBV}_{\mathrm{DNA}}^{* *}\left(\times 10^{3} \mathrm{IU} / \mathrm{ml}\right)$ & $10.2(0.46-98026)$ & $9.4(0.47-82018)$ & 0.1 \\
\hline $\mathrm{HAI}^{*}$ & $8( \pm 2.4)$ & $8( \pm 1.7)$ & 0.8 \\
\hline Fibrosis ${ }^{\star}$ & $2.8( \pm 1.5)$ & $3( \pm 2)$ & 0.5 \\
\hline Duration of TDF (months)* & $31( \pm 20)(\min -\max : 6-96)$ & $52( \pm 32)(\min -\max : 6-120)$ & 0.01 \\
\hline Duration of TAF (months)* & - & $12( \pm 6)(\min -\max : 3-23)$ & - \\
\hline $\operatorname{AST}^{\star}(\mathrm{U} / \mathrm{L})$ & $48( \pm 50)$ & $42( \pm 34)$ & 0.5 \\
\hline $\operatorname{ALT}^{*}(\mathrm{U} / \mathrm{L})$ & $67( \pm 80)$ & $51( \pm 51)$ & 0.4 \\
\hline Prevalence of abnormal ALT ${ }^{\star * \star}, \mathrm{n}(\%)$ & $23(43)$ & $11(41)$ & 0.7 \\
\hline Serum phosphorus ${ }^{\star}(\mathrm{mg} / \mathrm{dl})$ & $2.9( \pm 0.5)$ & $2.8( \pm 0.3)$ & 0.5 \\
\hline $\mathrm{GFR}^{\star}, \mathrm{ml} / \mathrm{min}$ & $99( \pm 13)$ & $90( \pm 15)$ & 0.02 \\
\hline \multicolumn{4}{|l|}{ Comorbid diseases } \\
\hline HT, n (\%) & $8(15)$ & $5(19)$ & 0.6 \\
\hline $\mathrm{DM}, \mathrm{n}(\%)$ & $6(11)$ & $3(11)$ & 0.9 \\
\hline $\mathrm{CKD}, \mathrm{n}(\%)$ & - & $3(11)$ & - \\
\hline \multicolumn{4}{|c|}{$\begin{array}{l}\text { M: Male, AST: Aspartate aminotransferase, ALT: Alanine aminotransferase, TDF: Tenofovir disoproxil fum } \\
\text { index, GFR: Glomerular filtration rate, DM: Diabetes mellitus, HT: Hypertension, CKD: Chronic kidney di } \\
* \text { : Mean ( } \pm \text { Standard deviation) } \\
* * \text { : Median (min-max) } \\
\text { ***: Normal ALT cutoffs for male } 41 \mathrm{U} / \mathrm{L} \text {, for female } 33 \mathrm{U} / \mathrm{L} \text { according to the reference laboratory } \\
\text { : Three patients with chronic kidney disease in the TAF group were not included in the statistical analysis }\end{array}$} \\
\hline
\end{tabular}


In the TAF group: The mean age of the patients was $48 \pm 15$ years, 16 of them (59\%) were male. The mean durations of TDF and TAF treatment were $52 \pm 32$ (range: 6-120) and $12 \pm 6$ (range: 3-23) months, respectively. Three (11\%) of the patients had HBeAg positivity and six $(22 \%)$ had a diagnosis of cirrhosis. As a comorbid disease; five (19\%) patients had hypertension, three (11\%) patients had diabetes mellitus, and three (11\%) patients had chronic kidney disease (CKD). One of these patients with CKD was receiving TDF from a renal dose, once in every other day (her GFR level was $43 \mathrm{ml} / \mathrm{min}$ ). The median HBV DNA level before the TDF treatment was $9.4 \times 103 \mathrm{IU} / \mathrm{ml}$. The mean HAI and fibrosis values were $8( \pm 1.7)$ and $3( \pm 2)$, respectively (Table 1$)$. The mean AST, ALT, GFR, and serum phosphorus level of the patients before the TDF treatment/at the time of the switch/after the TAF treatment were $42 / 22 / 21 \mathrm{U} / \mathrm{L}$, $48 / 23 / 22 \mathrm{U} / \mathrm{L}, 90 / 100 / 102 \mathrm{ml} / \mathrm{min}$, and $2.8 / 2.3 / 2.9$ $\mathrm{mg} / \mathrm{dl}$, respectively. Decrease in the mean values of transaminases and serum phosphorus level after the TDF treatment, and increase in the mean serum phosphorus level after the switch were significant (p: 0.01 and 0.05 , and 0.01 , respectively). There was a significant increase in GFR values under the TDF treatment (p: 0.03). While detectable HBV DNA was detected in two (7\%) patients under the TDF treatment, this was not observed in any patient after the TAF treatment. Abnormal ALT levels were detected in two (7\%) patients in both the TDF and TAF groups. One of these patients had grade-2 hepatosteatosis on ultrasonography. The other patient had liver cirrhosis. No HBsAg loss or HBeAg seroconversion was observed during the treatment course (Table 3).

When the baseline demographic, clinical, and laboratory characteristics were compared between the groups, there was no significant difference except for the duration of TDF treatment and the mean GFR levels. The duration of TDF use was significantly higher in the TAF group (p: 0.01 ). The mean GFR level was significantly lower in the TAF group (p: 0.02) (Table 1).

In addition, the mean GFR values of three patients switched due to low GFR showed a significant decrease from 56 to $49 \mathrm{ml} / \mathrm{min}$ under the TDF treatment and a significant increase from 49 to $62 \mathrm{ml} / \mathrm{min}$ after the TAF treatment (Figure 2). A significant improvement was observed in the total hip and spine $\mathrm{T}$ score of the patients who were switched to TAF due to osteoporosis (-1.8 \& -1.1 and $-2.7 \&-1.4$, respectively) (Figure 3). No side effects that could discontinue the treatment were observed either under the TDF treatment or during the TAF treatment.
Table 3. Changes in laboratory parameters of the patients switched from TDF to TAF ( $\mathrm{n}: 27$ )

\begin{tabular}{|c|c|c|c|c|}
\hline Variables & $\begin{array}{c}\text { Baseline } \\
\text { (before } \\
\text { TDF)a }\end{array}$ & $\begin{array}{l}\text { At the } \\
\text { time of } \\
\text { the switch } \\
\text { (before } \\
\text { TAF)b }\end{array}$ & $\begin{array}{c}\text { The latest } \\
\text { follow up } \\
\text { (after } \\
\text { TAF)c }\end{array}$ & $\mathbf{p}$ \\
\hline $\operatorname{AST}^{\star}(\mathrm{U} / \mathrm{L})$ & $42( \pm 34)$ & $22( \pm 6)$ & $21( \pm 7)$ & $\begin{array}{c}\text { a-b: } 0.01 \\
\text { b-c: } 0.9 \\
\text { a-c: } 0.01\end{array}$ \\
\hline $\operatorname{ALT}^{\star}(\mathrm{U} / \mathrm{L})$ & $48( \pm 43)$ & $23( \pm 12)$ & $22( \pm 10)$ & $\begin{array}{c}\text { a-b: } 0.01 \\
\text { b-c: } 0.9 \\
\text { a-c: } 0.01\end{array}$ \\
\hline $\begin{array}{l}\text { Prevalence of } \\
\text { abnormal ALT } \\
\text { n (\%) }\end{array}$ & $11(41)$ & $2(7)$ & $2(7)$ & $\begin{array}{l}\text { a-b: } 0.003 \\
\text { b-c: } 1 \\
\text { a-c: } 0.003\end{array}$ \\
\hline $\begin{array}{l}\text { Serum phosphorus* } \\
(\mathrm{mg} / \mathrm{dl})\end{array}$ & $\begin{array}{c}2.8 \\
( \pm 0.3)\end{array}$ & $2.3( \pm 0.4)$ & $2.9( \pm 0.6)$ & $\begin{array}{c}\text { a-b: } 0.05 \\
\text { b-c: } 0.01 \\
\text { a-c: } 0.8\end{array}$ \\
\hline $\mathrm{GFR}^{*}, \mathrm{ml} / \mathrm{min} \mathrm{g}$ & $90( \pm 15)$ & $100( \pm 14)$ & $102( \pm 15)$ & $\begin{array}{c}\text { a-b: } 0.03 \\
\text { b-c: } 0.6 \\
\text { a-c: } 0.01\end{array}$ \\
\hline HBsAg loss, $\mathrm{n}$ & - & 0 & 0 & \\
\hline $\begin{array}{l}\mathrm{HBeAg} \\
\text { seroconversion, } \mathrm{n}\end{array}$ & - & 0 & 0 & \\
\hline $\begin{array}{l}\text { Detectable HBV } \\
\text { DNA, n (\%) }\end{array}$ & 27 (100) & $2(7)$ & 0 & \\
\hline \multicolumn{5}{|c|}{$\begin{array}{l}\text { AST: Aspartate aminotransferase, ALT: Alanine aminotransferase, TDF: Tenofovir } \\
\text { disoproxil fumarate, TAF: Tenofovir alafenamide fumarate, GFR: Glomerular filtration } \\
\text { rate } \\
*: \text { Mean ( } \pm \text { Standard deviation) } \\
* * \text { : Median (min-max) } \\
\star * *: \text { Normal ALT cutoffs for male } 41 \mathrm{U} / \mathrm{L} \text {, female } 33 \mathrm{U} / \mathrm{L} \text { according to the reference } \\
\text { laboratory } \\
\text { g: Three patients with chronic kidney disease were not included in the statistical analysis }\end{array}$} \\
\hline
\end{tabular}

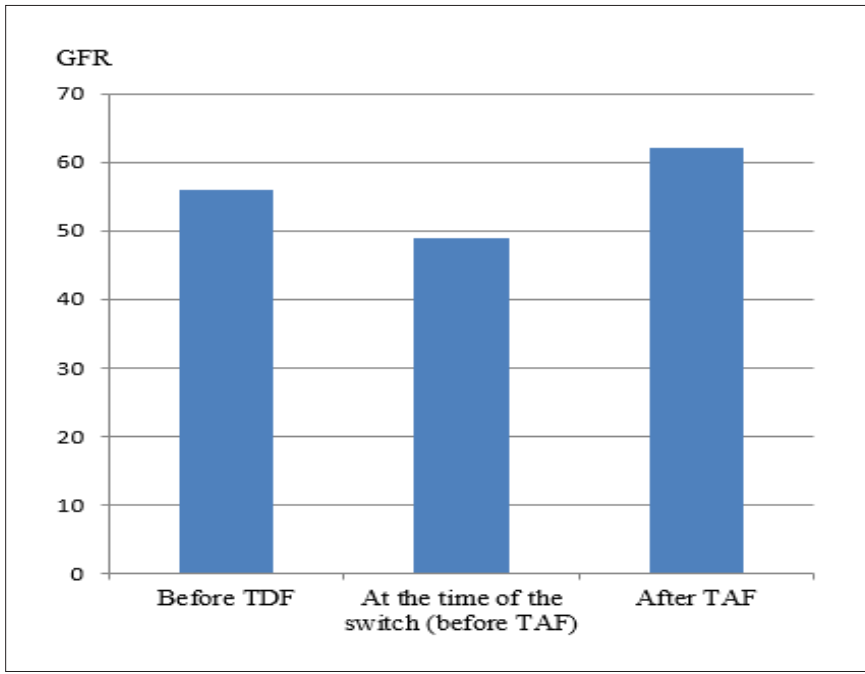

Figure 2. Mean changes in GFR in patients who are switched to TAF due to GFR $<60 \mathrm{ml} / \mathrm{min}$ (n: 3 )

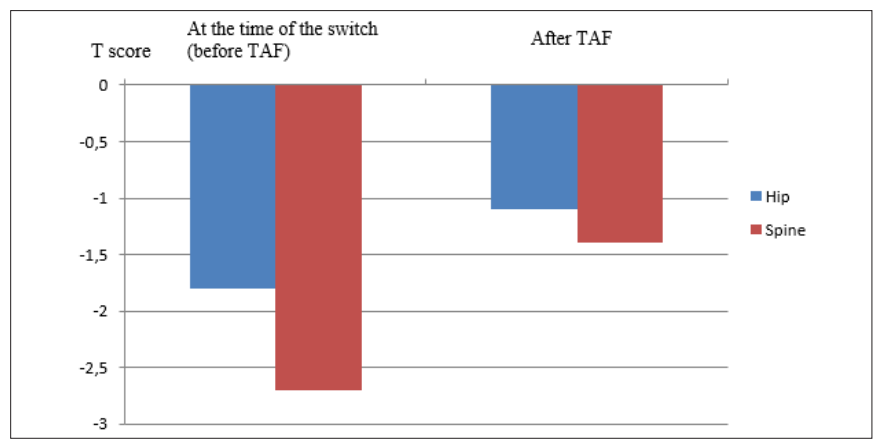

Figure 1. Mean changes in T score in patients who are switched to TAF due to osteoporosis (n: 2 ) 


\section{DISCUSSION}

Only very few studies have been carried out worldwide on real-life data of TAF in the treatment of CHB. In addition, when the published literature is searched, only one study has yet been reported from Turkey (21). In this respect, this study is valuable in that it contains the second real-life data of Turkey, even it has a small patient group.

Sustained suppression of viral replication with treatment in $\mathrm{CHB}$, reduces the level of liver inflammation, liver fibrosis, and the risk of HCC (22-24). Oral anti-virals, which are nucleos(t)ide analogs used in CHB treatment, are well tolerated and patient compliance is better the pegile interferon $(25,26)$. In the long-term use of oral antiviral agents, resistance development and some side effects have been encountered (27). TAF has recently started to be used in the treatment of CHB and has a very high resistance barrier (12). Free serum tenofovir, which is mainly responsible for the systemic side effects of TDF, is eliminated from the urinary system via the proximal tubules. This can cause proximal tubular damage, hypophosphatemia, proteinuria, and decreased GFR (28-31).

Long-term use of TDF in HIV-positive patients has been shown to have negative effects on renal functions and BMD (28-30,32). In phase 3 studies, it has been shown that TAF used in the treatment of CHB in recent years has a similar anti-viral activity to TDF and, it has more positive effects on renal functions and bone metabolism than TDF (14-16). Lampertico et al. (16) have demonstrated that TAF has a similar anti-viral activity with TDF in patients with CHB. In addition, TAF was superior to TDF in terms of ALT normalization (according to the 2018 American Association for the Study of Liver Diseases criteria) and improved GFR and BMD. In a study, Kaneko et al. (33) conducted on patients with $\mathrm{CHB}$, it was found that the use of TDF and TAF has similar anti-viral effects. However, it has been shown that there is a significant decrease in GFR as a result of using TDF for 48 weeks, and in patients who have switched from TDF to TAF, this decrease has been shown to improve significantly from the 4 th week. In addition, no significant change was detected in serum phosphorus levels in patients with 48 weeks of TDF use or switched from TDF to TAF, while a significant improvement was observed in the urinary $\beta 2 \mathrm{microglobulin} / \mathrm{creatinine}$ ratio showing improved proximal renal tubular function in the switched group. In another 96-week study comparing TDF and TAF in patients with CHB, it was shown that TDF and TAF had similar anti-viral activity, but TAF's effects on both ALT normalization and BMD and GFR were more positive (34).
As a result of the 24-week follow-up of $75 \mathrm{CHB}$ patients who were switched from TDF to TAF, a significant improvement was detected in BMD and some proximal renal tubular functions, while no change was detected in the mean GFR value (35). In another multi-center study, it has been revealed that TAF has more positive effects on BMD than TDF in the 2-year follow-up of patients with $\mathrm{CHB}$ (36). In a recent study, significant improvement was observed in proximal renal tubular functions (urinary beta2-microglobulin / creatinine and retinol-binding protein/creatinine ratios) and $\mathrm{BMD}$ in the 72 -week follow-up of $61 \mathrm{CHB}$ patients who were switched from TDF to TAF. However, it was determined that there was a decrease in the initial GFR values over time (96 \& $90 \mathrm{ml} / \mathrm{min})$. No significant change was found in serum phosphorus levels $(3.2 \& 3.1 \mathrm{mg} /$ $\mathrm{dl}$ ). They attributed this decrease in GFR to the basal chronic renal failure ground in some of the patients in the study (37).

In this study, similar to the literature, it has been shown that TAF has similar anti-viral activity with TDF. While there was no negative effect of TDF use on creatinine clearance, there was a significant increase in GFR level in the patients switched to TAF (Table 2 and 3). However, it was determined that the mean GFR value in three patients who switched to TAF due to low GFR $(<60 \mathrm{ml} / \mathrm{min})$ decreased significantly under the TDF treatment and increased significantly after the TAF treatment (Figure 2). It was noteworthy that the mean GFR values $(56 \mathrm{ml} / \mathrm{min}$ ) of these three patients at the beginning of treatment (before the TDF treatment) were significantly lower than the general average (99 and 90 $\mathrm{ml} / \mathrm{min}$ ) of all the patients. This situation suggested that TDF treatment causes a decrease in creatinine clearance only in the patients with low baseline GFR. However, long-term prospective studies involving large patient groups are needed to confirm this situation. In this study, it was found that serum phosphorus levels were significantly improved after the switch from TDF to TAF. This result showed that TAF had more positive effects on phosphorus metabolism. Similar to the literature, the total hip and spine $\mathrm{T}$ score values in our two patients who were diagnosed with osteoporosis while under the TDF treatment showed a significant improvement with the TAF treatment (Figure 3).

In TAF's pivotal phase 3 studies, it has been shown that TDF is superior to TAF in terms of HBsAg loss in patients with CHB (in the TDF group; $5 / 245$, in the TAF group; 0/243). During the treatment, detectable HBV DNA (> $20 \mathrm{IU} / \mathrm{ml})$ was detected in one patient in both groups. There was no significant difference between the two groups in terms of HBeAg seroconversion (16). In this study, HBsAg loss or $\mathrm{HBeAg}$ seroconversion was 
not observed in any of the patients. The reason for this may be the small number of the patients in our study and the short duration of our treatment follow-up. It was remarkable that in the current study, measurable levels of HBV DNA (> $20 \mathrm{IU} / \mathrm{ml}$ ) were detected under TDF treatment in two patients. When these patients were questioned for adherence retrospectively about whether they took their medicines every day, the patients stated that they were compliant and used their medicines regularly. In addition, it was found that the mean duration of TDF use of these patients was shorter than all the patients (17 \& 31-52 months). This may explain the presence of detectable HBV DNA in these patients.

Limitations of the study: The most important limitation of this study is that is being a retrospective study. In addition, the study contains a small number of patients.

\section{CONCLUSIONS}

It has been found that TAF, which has recently been used in the treatment of CHB in our country as well as in the world, has a similar anti-viral activity to TDF and, it is superior in terms of its effects on serum phosphorus levels, GFR, and BMD. In patients with CHB in whom TDF is initiated, serum phosphorus levels should be checked regularly before and after the treatment. At the same time, BMD annual follow-up is required during the TDF treatment, especially in individuals at risk for osteoporosis. In addition, it is thought that TDF does not effect creatinine clearance in patients with normal basal GFR levels. Prospective and long-term studies involving large patient groups are needed to reveal the real-life data of TAF in patients with $\mathrm{CHB}$ more clearly.

\section{ETHICAL DECLARATIONS}

Ethics Committee Approval: The study was approved by the ethics committee of Health Sciences University Bursa Yuksek Ihtisas Training and Research Hospital (Date: 17.02.2021, Decision No: 2011-KAEK-25 2021/02-03).

Referee Evaluation Process: Externally peer-reviewed.

Conflict of Interest Statement: The author has no conflicts of interest to declare.

Financial Disclosure: The author declared that this study has received no financial support.

Author Contributions: The author declare that he has participated in the design, execution, and analysis of the paper, and that he has approved the final version.

\section{REFERENCES}

1. Global Hepatitis Report 2017. Geneva: World Health Organization; 2017. Available at: http://apps.who.int/iris/ handle/10665/255016. Accessed April 23, 2021.

2. KaragozE, Tanoglu A. Clinical usefulness of HBsAg quantification in patients with chronic hepatitis B infection. Hepat Mon 2017; 17: e12293.

3. Hyun Kim B, Ray Kim W. Epidemiology of hepatitis B virus infection in the United States. Clin Liver Dis (Hoboken) 2018; 12: $1-4$.

4. Konerman MA \& Lok AS: Epidemiology, Diagnosis, and Natural History of Hepatitis B. In Sanyal AJ, Boyer TD, Lindor KD \& Terrault NA (Eds.), Zakim and Boyer's Hepatology: A textbook of liver disease, $7^{\text {th }}$ edition, Philadelphia; Saunders/Elsevier; 2018: pp. 474-84.

5. Abdul Basit S, Dawood A, Ryan J, Gish R. Tenofovir alafenamide for the treatment of chronic hepatitis B virus infection. Expert Rev Clin Pharmacol 2017; 10: 707-16.

6. Wright TL. Clinical trial results and treatment resistance with lamivudine in hepatitis B. Semin Liver Dis 2004; 24: 31-6.

7. Liaw YF. The current management of HBV drug resistance. J Clin Virol 2005; 34: 143-6.

8. Tenney DJ, Rose RE, Baldick CJ, et al. Two-year assessment of entecavir resistance in Lamivudine-refractory hepatitis B virüs patients reveals different clinical outcomes depending on the resistance substitutions present. Antimicrob Agents Chemother 2007; 51: 902-11.

9. Tenney DJ, Rose RE, Baldick CJ, et al. Long-term monitoring shows hepatitis $B$ virus resistance to entecavir in nucleosidenaïve patients is rare through 5 years of therapy. Hepatology 2009; 49: 1503-14.

10. Liu Y, Corsa AC, Buti $M$, et al. No detectable resistance to tenofovir disoproxil fumarate in $\mathrm{HBeAg}+$ and $\mathrm{HBeAg}$ - patients with chronic hepatitis B after 8 years of treatment. J Viral Hepat 2017; 24: 68-74.

11. Gara N, Zhao X, Collins MT, et al. Renal tubular dysfunction during long-term adefovir or tenofovir therapy in chronic hepatitis B. Aliment Pharmacol Ther 2012; 35: 1317-25.

12. Liu Y, Chang S, Martin R, Flaherty J, Mo H, Feierbach B. Characterization of hepatitis $\mathrm{B}$ virus polymerase mutations A194T and CYEI and tenofovir disoproxil fumarate or tenofovir alafenamide resistance. J Viral Hepat 2021; 28: 30-9.

13. Agarwal K, Fung SK, Nguyen TT, et al. Twenty-eight day safety, antiviral activity, and pharmacokinetics of tenofovir alafenamide for treatment of chronic hepatitis B infection. J Hepatol 2015; 62: $533-40$.

14. Chan HLY, Fung S, Seto WK, et al. Tenofovir alafenamide versus tenofovir disoproxil fumarate for the treatment of $\mathrm{HBeAg}$ positive chronic hepatitis B virus infection: a randomised, double-blind, phase 3, non-inferiority trial. Lancet Gastroenterol Hepatol 2016; 1: 185-95.

15. Buti M, Gane E, Seto WK, et al. Tenofovir alafenamide versus tenofovir disoproxil fumarate for the treatment of patients with $\mathrm{HBeAg-negative} \mathrm{chronic} \mathrm{hepatitis} \mathrm{B} \mathrm{virus} \mathrm{infection:} \mathrm{a}$ randomised, double blind, phase 3, non-inferiority trial. Lancet Gastroenterol Hepatol 2016; 1: 196-06.

16. Lampertico P, Buti M, Fung S, et al. Switching from tenofovir disoproxil fumarate to tenofovir alafenamide in virologically suppressed patients with chronic hepatitis B: a randomised, double-blind, phase 3, multicentre non-inferiority study. Lancet Gastroenterol Hepatol 2020; 5: 441-53.

17. Chan HLY, Marcellin P, Pan CQ, et al, editors. No Resistance to Tenofovir Alafenamide Detected Through 144 Weeks of Treatment in Patients With Chronic Hepatitis B [Poster 386]. AASLD: The Liver Meeting ${ }^{\oplus}$ 2018; 2018 09-13 November; San Francisco, CA. 
18. Amanzadeh J, Reilly RF Jr. Hypophosphatemia: an evidencebased approach to its clinical consequences and management. Nat Clin Pract Nephrol 2006; 2: 136-48.

19. Levey AS, Coresh J, Greene T, et al. Chronic Kidney Disease Epidemiology Collaboration. Using standardized serum creatinine values in the modification of diet in renal disease study equation for estimating glomerular filtration rate. Ann Intern Med 2006; 145: 247-54.

20. Ishak KG, Baptista A, Bianchi L, et al. Histological grading and staging of chronic hepatitis. J Hepatol 1995; 22: 696-9.

21. Karasahin O, Akdemir Kalkan I, Dal T, et al. Real-life data for tenofovir alafenamide fumarate treatment of hepatitis B: the pythagoras Cohort. Hepat Mon 2021 21: e104943.

22. Papatheodoridis GV, Lampertico P, Manolakopoulos S, Lok A. Incidence of hepatocellular carcinoma in chronic hepatitis B patients receiving nucleos(t)ide therapy: a systematic review. J Hepatol 2010; 53: 348-56.

23. Chang TT, Liaw YF, Wu SS, et al. Long-term entecavir therapy results in the reversal of fibrosis/cirrhosis and continued histological improvement in patients with chronic hepatitis B. Hepatology 2010; 52: 886-93.

24. Lin CL, Kao JH. Risk stratification for hepatitis B virus related hepatocellular carcinoma. J Gastroenterol Hepatol 2013; 28: $10-7$.

25. Terrault NA, Bzowej NH, Chang KM, et al. AASLD guidelines for treatment of chronic hepatitis B. Hepatology 2016; 63: 261-83.

26. Jafri SM, Lok AS. Antiviral therapy for chronic hepatitis B. Clin Liver Dis 2010; 14: 425-38.

27. Scaglione SJ, Lok AS. Effectiveness of hepatitis B treatment in clinical practice. Gastroenterology 2012; 142: 1360-8.

28. Casado JL. Renal and bone toxicity with the use of tenofovir: understanding at the end. AIDS Rev 2016; 18: 59-68.

29. Hall AM, Hendry BH, Nitsch D, Connolly JO. Tenofovirassociated kidney toxicity in HIV - infected patients: a review of the evidence. Am J Kidney Dis 2011; 57: 773-80.

30. Fernandez-Fernandez B, Montoya-Ferrer A, Sanz AB, et al Tenofovir nephrotoxicity: 2011 update. AIDS Res Treat 2011; 2011: 354908.

31. Koklu S, Gulsen MT, Tuna Y, et al. Differences in nephrotoxicity risk and renal effects among anti-viral therapies against hepatitis B. Aliment Pharmacol Ther 2015; 41: 310-9.

32. Haskelberg H, Hoy JF, Amin J, Ebeling PR, Emery S, Carr A STEAL Studey Group. Changes in bone turnover and bone loss in HIVinfected patients changing treatment to tenofoviremtricitabine or abacavir-lamivudine. PLoS ONE 2012; 7: e38377.

33. Kaneko S, Kurosaki M, Tamaki N, et al. Tenofovir alafenamide for hepatitis B virus infection including switching therapy from tenofovir disoproxil fumarate. J Gastroenterol Hepatol 2019; 34: 2004-10.

34. Agarwal K, Brunetto M, Seto WK, et al. GS-US-320-0110; GS US-320-0108 Investigators. 96 weeks treatment of tenofovir alafenamide vs. tenofovir disoproxil fumarate for hepatitis B virus infection. J Hepatol 2018; 68: 672-81.

35. Fong TL, Lee BT, Tien A, et al. Improvement of bone mineral density and markers of proximal renal tubular function in chronic hepatitis B patients switched from tenofovir disoproxil fumarate to tenofovir alafenamide. J Viral Hepat 2019; 26: 561-7.

36. Seto WK, Asahina Y, Brown TT, et al. Improved Bone Safety of Tenofovir Alafenamide Compared to Tenofovir Disoproxil Fumarate Over 2 Years in Patients With Chronic HBV Infection. Clin Gastroenterol Hepatol 2018: S1542-3565(18)30633-5.

37. Lee BT, Chang M, Lim C, Bae HS, Fong TL. Bone and renal safety profile at 72 weeks after switching to tenofovir alafenamide in chronic hepatitis B patients. JGH Open 2020; 5: 258-63. 